\title{
A Profile of National and State-level Marriage Rates in the U.S., 1880-2018: A Research Note
}

\author{
Krista K. Westrick-Payne \\ Department of Sociology \& Center for Family and Demographic Research \\ Williams Hall \\ Bowling Green State University \\ Bowling Green, Ohio 43402 \\ kristaw@bgsu.edu \\ 419-372-3115
}

\section{Funding}

This research was supported in part by the Center for Family and Demographic Research, Bowling Green State University, which has core funding from the Eunice Kennedy Shriver National Institute of Child Health and Human Development (P2CHD050959) and an R03 grant (R03HD103830-01). 


\begin{abstract}
This paper investigates national and state-level trends in the adjusted marriage rate in the United States spanning nearly 140 years. While dramatic shifts in American family throughout the $20^{\text {th }}$ century is a widely touted phrase, the trends in the geographic variation in marriage rates remains unknown. Using data from numerous Government publications we present visual representations of the adjusted marriage rate in the U.S. over a long historical time span (1880-2019) disaggregating the marriage rate by state. Our goal is to highlight both spatial (at the state-level) and temporal variation in marriage patterns in the U.S.
\end{abstract}

Keywords: marriage; marriage rates; national-level; state-level; place; geography; trends

\title{
Introduction
}

It is widely acknowledged that the American family has been undergoing dramatic changes. Specifically, Ruggles (2012) asserts "the greatest period of change in the family was the twentieth century" highlighting the period between 1920 and 1960 as a source of especially rapid change. While this view is widely accepted among family scholars an ongoing debate remains regarding how these changes were shaped by the geography of the American family, and comparatively little spatial analysis has been conducted (Ruggles, 2012). Among the limited scholarship on geographic differences in family life in the U.S., "place" has been found to be of consequence. National trends mask substantial spatial differences in marriage (Lesthaghe \& Neidert, 2006; Livingston, 2018; Manning, Payne, \& Stykes, 2017). One source of these differences may be attributable to the fact that marriage regulation in the U.S. is- for the most part-relegated to states. The result is substantial variation by state in the numerous laws that govern marital behavior-laws that may have a significant impact on individual human behavior (Cott, 2002). States also vary in socioeconomic and political contexts leading to the implementation and proliferation of policies that may or may not support marriage. Our understanding of American marriage rates over time has been hindered by solely a national 
focus. This paper addresses two key questions. First, we determine the national and state-level trends in the adjusted marriage rate in the U.S. since 1900 focusing on differentials based on the definition of rates at 10-year intervals. Second, we assess variation over time and geography (states) and examine differing patterns. This paper provides an expansion of a national portrait of trends in marriage by highlighting state-specific patterns.

\section{Background}

The institution of marriage is, of course, at the very foundation of our social organization, and all influences that affect that institution are of vital concern to the people of the whole country - President Theodore Roosevelt (U.S. Bureau of the Census 1909a).

Current research supports the validity of concerns regarding the institution of marriage raised at the turn of the 20th century. Marriage remains important because of its influence on the formation and stability of families in the United States. It is a core institution defining the social and community context of individual's lives. Healthy People 2030 recognizes that people's relationships and interactions with family can have a significant impact on their overall health and wellbeing. At the aggregate level, marriage also influences many other aspects of American life including, but not limited to, fertility, economics, politics, and social policy and as such remains of great sociological importance (Amato \& Beattie, 2011; Glass \& Levchak, 2014; Lesthaeghe \& Neidert, 2006; Manning, Payne \& Stykes, 2015; Manning, Payne, Zugarek, \& Stykes, 2016; Manning, Brown, Payne, \& Wu, 2014; Ruggles, 2012; Schaller, 2012). While few would argue the continued centrality and importance of marriage in the lives of Americans, the political organization of the United States provides challenges to a complete understanding of the institution of marriage 


\section{Variation in Marriage Laws}

There is substantial variation in state-level laws regarding marriage in the U.S. because it is chiefly regulated by the individual states (Cott, 2002). Specifically, the Supreme Court grants the states permission to "reasonably regulate the institution" in that they are allowed to decide who is permitted to marry and how marriages can be dissolved. The scope of state-level regulations regarding marriage are confined to 4 broad areas - common law marriage, age of consent, medical examinations, and waiting periods. However, historically, two important limitations have been placed on states regarding their regulation of marriage. The first is regarding interracial marriage, in which the Supreme Court ruled in Loving v. Virginia that prohibiting interracial marriage was unconstitutional. The second is regarding marriage to same-gender couples, in which the Supreme Court ruled it was unconstitutional to prohibit the marriage of same-gender couples in Obergefell v. Hodges.

The organization of the U.S. political system means policies effecting American lives stem from multiple levels of government, including local, state, and federal levels (Brotherson \& Duncan, 2004). The afore mentioned same-gender marriage represents one of the most recent concrete examples of this. The state-level legal journey began in 1995 when Utah became the first state to enact a Defense of Marriage Act (DOMA), which asserted marriage was between one man and one woman. In 1996, President Clinton signed the federal DOMA, which upheld a state's right to ban same-gender marriage AND prohibited the federal government from recognizing samegender marriage. What followed was a varied conglomeration of state and federal laws and policies related to the issue that eventually culminated in the Supreme Court ruling that declared the unconstitutionality of state-level bans on marriages between couples of the same gender (see Pew, 2015 for detailed timeline). These multi-level sources of influence present challenges in 
understanding the effects of place on marital behavior and necessitate the examination of behavior at different geographic levels.

\section{A Brief History of Marriage in the U.S.}

A national portrait of the American family reveals dramatic changes in marriage throughout the $20^{\text {th }}$ and into the first two decades of the $21^{\text {st }}$ century. Today, the median age at first marriage is at a historic high point, surpassing 30 among men and 28 among women (U.S. Census Bureau, 2021). Fewer than half of American women are currently married - at 46\%, this represents a 118-year low-point. At its peak in 1960, 65\% of women were currently married (Schweizer, 2020b). Bloome and Ang (2020) predict future steep declines in the probability of ever marrying (see also Martin, Astone, \& Peters, 2014). Even though marriage levels have recently been declining, Americans still hold marriage in high regard. In fact, the legalization of marriage to same-gender couples demonstrate the importance of marriage. Indeed, this issue brought to light the strong practical value of marriage in the U.S. with the more than 1,000 federal benefits that accrue to married couples (Badgett, 2010; Kuperberg, 2012). When asked Americans profess an enduring desire and expectation to marry (Allred, 2019a), albeit at later ages (Allred, 2019b). They also agree that it is important to living a fulfilling life (Pew, 2019).

Most of the evidence about marriage declines has focused on the national level with relatively little attention to state-level patterns (e.g., Coontz, 2005; Fitch \& Ruggles, 2000; Lee \& Payne, 2010; Rogers \& Thornton, 1985; Schweizer, 2020b). This is problematic because states not only determine some parameters around marriage but there is ample recent evidence of differentials in marriage rates according to state (Glass \& Levchak, 2014; Manning, Payne \& Stykes, 2015; Manning, Payne, Zugarek, \& Stykes, 2016; Reynolds, 2020). In recent years the states with the 
highest marriage rates are typically Utah and Wyoming and lowest rates are Rhode Island and Delaware (Payne, 2009; Reynolds, 2020). In 2019 the rates ranged widely across states from 49.5 marriages per 1,000 unmarried in Wyoming to over half that level, 21.4, in Rhode Island. Despite this state variation little attention has been paid to historical trends in the state-level marriage rates.

\section{The History of Marriage and Divorce Data Reporting}

A major contributing factor in our inability to chart/examine change over time was the deterioration and defunding of the federal marriage and divorce vital statistics system. The systems involved in the collection, accumulation, and publication of marriage and divorce records in the United States is long and varied. The resulting descriptive studies of historical patterns of marriage in the United States have thus been covered extensively by many different federal agencies over the years.

Data for the years 1867-1886 were provided by the Commissioner of Labor. In 1916 the Bureau of the Census took over and published reports for the years 1916 and 1922-1932. Efforts stalled until after the end of World War II and were not picked back up until 1949—-this time by the National Office of Vital Statistics — and published for the years 1950, 1952, and 1957-1959. Beginning in 1960 the National Center for Health Statistics began compiling and publishing these data. The collection of detailed statistics was made possible by the establishment of the marriage-registration area (MRA) in 1957 and in 1958 the divorce-registration area (DRA). Beginning in 1960, samples of marriage and divorce records were taken from the MRA and DRA to provide detailed data (beyond total counts) for the first time since 1932. Collection of detailed data, however, were suspended in 1996. The most recent and comprehensive analyses on 
marriage was published in the Advance Report of Final Marriage Statistics, 1989-90. From June of 2003 through 2009 provisional data on state-level marriages were published in the NCHS National Vital Statistics Reports monthly provisional data series. Currently the National Center for Health Statistics only provides national counts of marriages and crude marriage rates as well as state-level crude marriage rates. While the American Community Survey has filled the

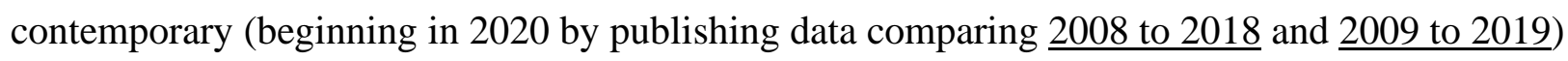
gap by calculating and making available state-level adjusted marriage rates via Census Infographics and Visualizations, these rates are not comparable to historical rates because they are based on the current state of residence of the individual who married and not the state in which the marriage occurred.

Recognizing the need for even more detailed data collection efforts and with the support of federal grants, individual researchers have endeavored to archive and disseminate data on marriage and divorce. First, the Glass NSF project ("Red States, Blue States and Divorce") accumulated the 2000 county marriage and divorce data, and the National Center for Family \& Marriage Research (NCFMR) helped to complete the data collection and release the data. Second, in 2013, NIH (National Institute of Health) funded the Manning project "Measuring Marriage \& Divorce at the County Level" which compiled the 2010 county marriage and divorce data. The 2000 and 2010 data are available on the NCFMR web page. Third, a NIH-funded collaboration between the NCFMR at Bowling Green State University (BGSU) and the National Historical Geographic Information System (NHGIS) at the University of Minnesota (UMN), “Archiving County and State Nuptiality Data" was supported in 2017. County-level data on marriages and divorces for the years 1867-1988, 2000, and 2010 were harmonized and made available in standardized machine-readable documentation and high-precision GIS boundary 
files via NHGIS.

\section{Paper Goals}

The primary aim of this paper is to present visual representations of the marriage rate in the United States over a long historical time span (1880-2019) disaggregating the adjusted marriage rate by state. First, while national level trends have been presented, we consider an alternative measure for the rates at 10-year intervals. Second, our goal is to highlight both spatial and temporal variation in marriage patterns in the United States. Ruggles (2012) emphasizes that while “...fertility and mortality transitions have been intensively studied, there has been comparatively little research on the family transition." While much of Ruggles work focuses on specific living arrangements of kin, we assert marriage is an important indicator of "family transitions" as far as it is a way of formally establishing families, dictates levels and types of financial supports, offers specific legal protections, and the dissolution of a marriage is a source of family instability. The importance of examining state-level variations is of even greater import, in that marriage as an institution is subject to state-level regulations in the U.S. which can vary, highlighting the potential impact of state-level laws on individual behaviors. To achieve this aim, we draw on recently archived data that permits our examination of national and state-level variation in the adjusted marriage rate among women over time in the U.S.

\section{Data and Methods}

Consistent with historical and contemporary reports on marriage, we present two measures of the marriage rate. The first is what we refer to as the crude marriage rate, defined as:

(\# marriages / total population) $* 1,000$. 
We refer to the second, more refined rate, as the adjusted marriage rate, defined as:

(\# marriages / \# unmarried women aged 15 and older) * 1,000.

We focus most of our attention on the adjusted marriage rate, which we assert is a superior measure as compared to the crude marriage rate because it restricts our descriptive analysis to the specific population "at risk" of entering a marriage. Ruggles (2012) highlights the importance of doing so, particularly when comparing different geographic locations that may have different age compositions and advocates for "pay[ing] as much attention to denominators as to numerators."

The data for this project come from multiple sources. Table 1 provides the breakdown of the associated measures for each data year and the publication title for the national crude and adjusted marriage rates over time and Table 2 provides the same for the state-level marriage rates over time. Please note, measures related to marriages are available in several different reports, and while many estimates are consistent over time, not all are. When choosing sources, we opted to use those most recently published for any given year, for these were the most consistent across sources over time.

\section{[TABLE 1 ABOUT HERE]}

All national-level crude rates from 1870 through 2019 and national-level adjusted rates for 1880, 1890, 1900, 1910, 1920, and 1930-1993 come directly from reports and tables published by the U.S. Census Bureau or the National Center for Health Statistics. Because adjusted rates for the years 1994-2019 are not published, they had to be computed by two methods. First, for years 1994-1999 the number of marriages is provided in reports (the numerator), but the number of 
unmarried women aged 15 and older are not (the denominator). We obtained the denominator from IPUMS-CPS - the largest nationally representative population sample that provides singleyear estimates of the U.S. population by gender, age, and marital status for single-years in the 1990s. For the years 2000-2019 NCHS provides crude marriages rates, therefore, to determine the adjusted marriage rates we first had to deconstruct the crude rates to determine the number of marriages in each year. Because the crude rates are based on the total U.S. population, we used IPUMS-USA to acquire American Community Survey data - the largest nationally representative population sample that provides single-year estimate of the U.S. population by gender, age, and marital status in the 2000s and 2010s. We used the ACS data to deconstruct the crude marriage rates to obtain the number of marriages (e.g., the adjusted rate numerator) as well as to estimate the number of unmarried women aged 15 and older (the denominator).

The state-level data also come from reports and tables published by the U.S. Census Bureau or the NCHS (formerly the National Office of Vital Statistics). For decennial years 1890, 1900, 1930, 1940, 1950, 1960, the state-level adjusted marriage rates were taken directly from a report published by the National Vital Statistics System titled 100 Years of Marriage and Divorce Statistics United States 1867-1967. For decennial year 1970, the adjusted marriage rate came from the report Vital Statistics of the United States 1970, Volume III Marriage and Divorce. The adjusted marriage rates for the year 1980 were computed from the number of marriages (numerator) per state from Table 2 in the Advance Report of Final Marriage Statistics, 1989 and 1990 and the number of never married women aged 15 and older (denominator) from 1980 U.S. Decennial Census data provided by IPUMS-USA. For decennial years 1990, 2000, 2010, and 2019 NCHS provides crude marriages rates, therefore - like with the national-level rates - to determine the adjusted marriages rates we first had to deconstruct the crude rates to determine 
the number of marriages in each state in each year. We also used IPUMS-USA to acquire Decennial Census and American Community Survey data at the state-level. We used the data to deconstruct the crude marriage rates to obtain the number of marriages (e.g., the adjusted rate numerators) as well as to estimate the number of unmarried women aged 15 and older in each state (the denominators).

\section{Results}

\section{National Trends}

Figure 1 represents the crude marriage rate (solid line on right y-axis) and the adjusted marriage rate (dashed line on the left y-axis) occurring in each decennial year from 1880-2010 and the year 2019 in the United States. Plotting these trends together, but on different axes, allows us to see similarities and dissimilarities in the general trends over time. Through 1940, the trends are remarkably similar. The highest adjusted marriage rate was associated with the year 1920 when there were 93.1 marriages for every 1,000 unmarried women aged 15 and older in the U.S. The year 1920 also represents the second highest crude marriage rate when there were 12.0 marriages for every 1,000 persons which was only 0.1 lower than the highest crude rate in 1940 .

\section{[FIGURE 1 ABOUT HERE]}

In 1930, both the adjusted and crude rates dipped, followed by dramatic increases in both rates. It is the timing of this second round of increases where the patterns of the two rates begin to differ. The crude rate increased through 1940 and then subsequently dropped to a rate of 8.5 marriages per 1,000 people in 1960. The adjusted rate did not hit a peak again until 1950 (at 90.2) and subsequently dropped in 1960 to rate of 73.5 marriages per 1,000 unmarried women aged 15 and 
older. Both the crude and adjusted rates increased from 1960 to 1970.

Following 1970 the adjusted marriage has precipitously declined. In 2019 there were only 28.4 marriages per unmarried women aged 15 and older which is about one-third the rate of the peak adjusted marriage rates in 1920 and 1950. The crude marriage rate decline began ten years later in 1980. As with the adjusted marriage rate, 2019 is associated with the lowest crude marriage rate in the United States since these data have been collected.

\section{State-level Variation}

Figures $3 \mathrm{a}$ and $3 \mathrm{~b}$ are scatter plots for each state and the U.S. from 1900 through 2019 in which we have available data. State-level data were not available for decennial years 1910 or 1920 . These years have a single data plot (the diamond shape) signifying the adjusted marriage for the U.S. In this example, each state is represented by a dot and all the dots are placed along the axis for each respective decennial year, with proximate dots overlapping. One of the more striking revelations of Figure 4 is the range of adjusted marriage rates among U.S. states, particularly in 1940 and 1950. By 2010 and in 2019 the rate had dropped throughout nearly all fifty states and DC and was much more concentrated. Since 1940, Nevada and since 1990, Hawaii have been outliers, with large shares of non-resident marriages (AKA marriage "mills").

\section{[FIGURES 2A and 2B ABOUT HERE]}

Figures $4 \mathrm{a}$ and $4 \mathrm{~b}$ provide a more concise visualization of the dispersion of state-level adjusted marriage rates over time. Specifically, Figure 4a depicts the first quartile (the green line), the median (e.g., second quartile represented by the dark blue line), and the third quartile (the gray line) of the state-level rates. Figure $4 \mathrm{~b}$ depicts the change in the interquartile range (quartile 3 
minus quartile 1) over time. These figures confirm a decrease and concentration of state-level marriage rates over time and provide evidence of dramatic change from 1930 through 1960. In 1940 we observed the largest interquartile range among U.S. states at 69.2 marriages and the smallest in 2019 of only 7.0 marriages. Thus, as marriage rates have declined the level of variation across states has narrowed.

\section{[FIGURES 3A and 3B ABOUT HERE]}

Using the values associated with first and third quartiles and the interquartile range we identify state outliers in each decennial year by calculating the lower and upper fence values. These outliers can signal important data context and/or caveats. Regarding context, they may be an indicator of states known as marriage "mills," places with temperate weather and beautiful scenery or less restrictive marriage laws. Regarding caveats, they may also be a signal of data quality issues. Regardless, outliers may indicate places in need of more investigative scrutiny. There were no states with adjusted marriage rates below the lower fence, however there were several states with rates above the upper fence at each decennial year examined. Looking at Table 3, some trends emerge. Not surprisingly, Nevada is found to be an outlier in each decade examined since 1900. Early on Arizona (1930, 1940, and 1950), New Mexico (1930, 1950, and 1960), and Alaska (1950, 1960, 1970) were outliers in three decades. Hawaii emerges as an outlier in 1990 and remains so through 2019, spanning nearly four decades. Beginning in 1960, Idaho is an outlier in 4 out of 7 subsequent time points examined (1960, 1990, 2010, and 2019). Finally, Utah emerges as an outlier in 2010 and remains so in 2019.

\section{[TABLE 3 ABOUT HERE]}

Next, we determine how the dispersion of the adjusted marriage rate changed over time with 
respect to states as geographically defined spaces. Figure 5 seeks to illustrate an answer to this question by displaying twelve temporally sequential maps, spaced roughly 10 years apart (the last time point is 9 years from the second -to-the-last time point due to data constraints). In each map the states with the highest adjusted marriage rates, determined by those states in the fourth quartile of the distribution of state-level rates by year, are shaded dark (the outliers, discussed in the previous section as those states with rates above the upper fence of the distribution of rates are the darkest and outlined in orange) with the remaining lower three quartiles represented as a light teal.

\section{[FIGURE 4 ABOUT HERE]}

Since 1890 the states with the majority of the highest adjusted marriage rates were all found in the Western or Southern regions of the U.S. In eight out of the twelve decades examined, the West had the largest number of states in the fourth quartile, the South had the largest number in two (1930 and 1990), and the West and South tied in two (1900 and 2000). From 1900 through 1930 it appears marriage was most concentrated in the South. However, a retraction followed from 1940 through 1980 with marriages being concentrated in the West. In 1990 the South again had the largest share. The most significant geographical shift happened following 1990. By 2019 there had been a large retraction in marriage in the South. The evident Southern marriage-belt of 1990 had disappeared, leaving only two Southern states in the fourth quartile (Arkansas and Tennessee). In 2019, Maine and Vermont emerged among the states with the nation's highest adjusted marriage rates. One mid-western state—South Dakota — made the top of the list with the remaining nine states in the Western region. Interestingly beginning in 1970 South Dakota remained in the fourth quartile. 
Figure 6 also illustrates twelve temporally sequential maps, spaced roughly 10 years apart. In this series, each maps the states with the lowest adjusted marriage rates, determined by those states in the first quartile of the distribution of state-level rates by year, are shaded a light orange with the remaining lower three quartiles represented as a rust/brown.

\section{[FIGURE 5 ABOUT HERE]}

In 1890 the states with the lowest adjusted marriage rates were all found in either the Southern or Northeastern region of the U.S. - over half were in the Northeast (54\%). Through 2010 the Northeast is the modal region (or tied as the modal region) in the lowest quartile. Beginning in 1930 it appears there is a creep towards the Midwest and South. 1940 represents the decade with the most even distribution by region with $23 \%$ in the West, $15 \%$ in the South, $31 \%$ in the Midwest, and 31\% in the Northeast. As was with the fourth quartile, the most significant geographical shift happened following 1990. By 2019, only four Northeastern states were in the first quartile, four states from the Midwest, five from the South, and none from the West.

\section{Discussion}

The primary aim of this paper was to visually represent the marriage rate in the United States over a long historical time span at both the national and state-level. More specifically, we endeavored to highlight both spatial and temporal variation in U.S. marriage patterns. Prior work indicates significant state-level variation in marriage and family behavior over time, particularly from 1920 through 1960 (Ruggles, 2012). Our analyses generally support these conclusions; however, it highlights distinct types of change. Regarding national trends, the period from 1920 through 1950 was very dynamic with large increases followed by large decreases which coincided with the ending of WWII. The years of the 1960s and 1970s were a time of correction 
and the examination of the adjusted marriage rate as compared to the crude rate indicates more of a plateau as opposed to an increase in marriage. The time following the 1970 s may also be categorized as representing one of dramatic change, albeit not one of dynamism, but one of precipitous decline.

Further, as state-level adjusted marriage rates declined so too has the state-level variation as was measured by the interquartile range. The examination of temporally sequential maps allowed for further exploration of the geographic dispersion of the adjusted marriage rate. This revealed a significant shift following 1990. While the South had developed a reputation as the marriagebelt, by 2019 there had been such a large retraction in marriage among Southern states only two states were found to be in the fourth quartile (Arkansas and Tennessee). The portrait this examination paints is one that reveals change in state-level variation, leading to the conclusion that geography does influence the American family and this influence has changed over time.

This paper makes several important contributions, but there are some limitations. First, while every effort was made to access and harmonize data to provide complete examination of the adjusted marriage rate in the U.S. over time limitations remain due to a lack of available data. More specifically, national-level adjusted marriage rates are not available prior to 1930. Second, regarding state-level adjusted marriage rates yearly data for years prior to 1999 are also unavailable, often because state-level estimates of the number of unmarried women aged 15 and older (the denominator) are not available. A third limitation is that these locations represent the states in which marriages took place, not necessarily where newly married people were living.

In sum, while this descriptive study shows dramatic shifts in marriage behavior over time, and more specifically distinct types of change, we see it as a starting point for future more in-depth 
explorations. Despite the lapse in the U.S. vital statics system, the continued archiving efforts of social science researchers enable the continuation of this work. The availability of these data opens the door to nested/multi-level models over time. Coupling these data with other individuallevel data would allow for the examination of the effects of state-level laws and policies on the marital behavior of individuals over time in the United States. 


\section{References}

Allred, C. (2019a). High school seniors' expectations to marry, 2017. Family Profiles, FP-19-11. Bowling Green, OH: National Center for Family \& Marriage Research. https://doi.org/10.25035/ncfmr/fp-19-11

Allred, C. (2019b). High school seniors' ideal time to marry, 2017. Family Profiles, FP-19-12. Bowling Green, OH: National Center for Family \& Marriage Research. https://doi.org/10.25035/ncfmr/fp-19-12

Amato, P. R. \& Beattie, B. (2011). Does the unemployment rate affect the divorce rate? An analysis of state data 1960-2005. Social Science Research, 40(3), 705-715. https://doi.org/10.1016/j.ssresearch.2010.12.012

Badgett, M. V. L. (2010). The economic value of marriage for same-sex couples. Drake Law Review, 58, 1081-1116.

Bloome, D. \& Ang, S. (2020). Marriage and union formation in the Unites States: Recent trends across racial groups and economic backgrounds. Demography, 57(5), 1753-1786. https://doi-org.ezproxy.bgsu.edu/10.1007/s13524-020-00910-7

Brotherson, S. E. \& Duncan, W. C. (2004). Rebinding the ties that bind: Government efforts to preserve and promote marriage. Family Relations, 53(5), 459-468. https://www.jstor.org/stable/20456762

Cott, N. F. (2002). Public Vows: A History of Marriage and the Nation. Harvard University Press.

Coontz, S. (2005). Marriage, A History. Penguin Group.

Eickmeyer, K. J., Payne, K. K., Brown, S. L., \& Manning, W. D. (2017). Crossover in the median age at first marriage and first birth: Thirty-Five years of change. Family Profiles, FP-17-22. Bowling Green, OH: National Center for Family \& Marriage Research. https://doi.org/10.25035/ncfmr/fp-17-22

Fitch, C. A. \& Ruggles, S. (2000). Historical Trends in Marriage Formation: The United States 1850-1990. In Waite, Linda J., Christine Bachrach, Michelle Hindin, Elizabeth Thompson, and Arland Thornton. (Eds.), The ties that bind: Perspectives on marriage and cohabitation (pp.56-90). New York: Aldine de Gruyter. 
Glass, J. \& Levchak, P. (2014). Red state, blue states, and divorce: Understanding the impact of conservative Protestantism on regional variation in divorce rates. American Journal of Sociology, 119(4), 1002-1046. https://www.jstor.org/stable/10.1086/674703

Hayford, S. R., Guzzo, K. B., \& Smock, P. J. (2014). The decoupling of marriage and parenthood? Trends in the timing of marital first births, 1945-2002. Journal of Marriage and Family, 76(3), 520-538.

Kuperberg, A. (2012). Reassessing differences in work and income in cohabitation and marriage. Journal of Marriage and Family, 74(4), 688-707. https://doi.org/10.1111/j.17413737.2012.00993.x

Lee, G. R. \& Payne, K. K. (2010). Changing marriage patterns since 1970: What's going on, and why? Journal of Comparative Family Studies, 41(4), 537-555. Www.jstor.org/stable/41604567

Lesthaghe, R. J. \& Neidert, L. (2006). The second demographic transition in the United States: Exception or textbook example? Population and Development Review, 32(4), 669-698. https://www.jstor.org/stable/20058923

Livingston, Gretchen (2014). 'Four-in-Ten Couples are Saying 'I Do,' Again.” Washington, D.C.: Pew Research Center, November. Retrieved February 19, 2021: https://www.pewresearch.org/social-trends/wp-content/uploads/sites/3/2014/11/2014-1114_remarriage-final.pdf

Livingston, Gretchen (2018). "Family life is changing in different ways across urban, suburban and rural communities in the U.S.” Washington, D.C.: Pew Research Center, June. Retrieved February 19, 2021: https://www.pewresearch.org/fact-tank/2018/06/19/familylife-is-changing-in-different-ways-across-urban-suburban-and-rural-communities-in-theu-s/

Manning, W. D., Brown, S. L., Payne, K. K., \& Wu, H.S. (2014). Health marriage initiative spending and U.S. Marriage \& Divorce Rates, a state-level analysis. Family Profiles, FP14-02. Bowling Green, OH: National Center for Family \& Marriage Research. http://www.bgsu.edu/content/dam/BGSU/college-of-arts-andsciences/NCFMR/documents/FP/FP-14-02_HMIInitiative.pdf 
Manning, W. D. \& Carlson, L (2021). Trends in cohabitation prior to marriage. Family Profiles, FP-21-04. Bowling Green, OH: National Center for Family \& Marriage Research. https://doi.org/10.25035/ncfmr/fp-21-04

Manning, W. D. \& Payne, K. K. (2021). Measuring marriage and cohabitation: Assessing samesex relationship status in the current population survey. Demography, 58(3), 811-820. https://doi.org/10.1215/00703370-9162213

Manning, Payne \& Stykes (2015). “Counting Marriages: Comparisons of 2010 Marriage Rates Across Counties and States.” Population Association of America, San Diego, CA.

Manning, W. D., Payne, K. K., \& Stykes. B. (2017). Counting marriages in the United States: The value of county-level administrative data. Statistical Journal of the IAOS, 33(3), 719725. DOI: $10.3233 /$ SJI-160338

Manning, Payne, Zugarek, \& Stykes (2016). The Shifting Geography of Divorce Rates Across Counties and States, 2000-2010” Population Association of America (Poster Presentation, Award Recipient), Washington, DC.

Martin, S., Astone, N., \& Peters, H. (2014). Fewer marriages, more divergence: Marriage projections for millennials to age 40. Washington, DC: Urban Institute. Retrieved from https://www.urban.org/sites/default/files/publication/22586/413110-Fewer-MarriagesMore-Divergence-Marriage-Projections-for-Millennials-to-Age-.PDF

Martin J. A., Hamilton, B. E., Osterman, M. J. K., et al. (2019). Births: Final data for 2018. National vital statistics reports; vol. 68 no. 13. Hyattsville, MD: National Center for Health Statistics. https://www.cdc.gov/nchs/data/nvsr/nvsr68/nvsr68_13-508.pdf McCarthy, J. (2018, May 23). Two in three Americans support same-sex marriage. Gallup Politics. Retrieved 2-19-2021 from https://news.gallup.com/poll/234866/two-threeamericans-support-sex-marriage.aspx

National Center for Health Statistics (2019). Key statistics from the National Survey of Family Growth, 2015-2017 NSFG (National Survey of Family Growth). Retrieved February 19, 2021: https://www.cdc.gov/nchs/nsfg/key_statistics_2015_2017.htm

Pew Research Center (June 2015). "Same-Sex Marriage, State by State.” Retrieved March 5, 2021: https://www.pewforum.org/2015/06/26/same-sex-marriage-state-by-state/ 
Pew Research Center (May 2017). "Intermarriage in the U.S. 50 Years After Loving v. Virginia." Retrieved February 19, 2021: https://www.pewresearch.org/socialtrends/2017/05/18/intermarriage-in-the-u-s-50-years-after-loving-v-virginia/

Pew Research Center (November 2019). "Marriage and Cohabitation in the U.S."

Rodgers, W. L. \& Thornton, A. (1985). Changing patterns of first marriage in the United States. Demography, 22(2), 265-279. https://www.jstor.org/stable/2061181

Ruggles, S. (2012). The future of historical family demography. Annual Review of Sociology, 38(18), 423-441. https://doi.org/10.1146/annurev-soc-071811-145533

Sassler, S. \& Lichter, D. T. (2020). Cohabitation and marriage: Complexity and diversity in union-formation patterns. Journal of Marriage and Family, 82(1), 35-61. https://doiorg.ezproxy.bgsu.edu/10.1111/jomf.12617

Schaller (2012). Local labor market shocks and family outcomes. (Publication No. 3540792) [Doctoral dissertations, University of California Davis]. ProQuest Dissertations Publishing.

Schweizer, V. (2019). The retreat from remarriage, 1950-2017. Family Profiles, FP-19-17. Bowling Green, OH: National Center for Family \& Marriage Research. https://doi.org/10.25035/ncfmr/fp-19-17

Schweizer, V. J. (2020a). Women who gave birth within the past 12 months, 2018. Family Profiles, FP-20-17. Bowling Green, OH: National Center for Family \& Marriage Research. https://doi.org/10.25035/ncfmr/fp-20-17

Schweizer, V. J. (2020b). Marriage: More than a century of change. Family Profiles, FP-20-21. Bowling Green, OH: National Center for Family \& Marriage Research. https://doi.org/10.25035/ncfmr/fp-20-21

U.S. Census Bureau, Current Population Survey, March and Annual Social and Economic Supplements. Table MS-2 Estimated Median Age at First Marriage, Sex: 1890 to the Present. Retrieved February 19, 2021: https://www2.census.gov/programssurveys/demo/tables/families/time-series/marital/ms2.xls 
Table 1. National-Level Data Sources

\begin{tabular}{|c|c|c|c|c|c|}
\hline \multirow[b]{2}{*}{ Years } & \multicolumn{4}{|c|}{ Measures } & \multirow[b]{2}{*}{ Source Title (for Adjusted Rate, Crude Rate, or Numerator) } \\
\hline & $\begin{array}{l}\text { Adjusted } \\
\text { Rate }\end{array}$ & $\begin{array}{l}\text { Crude } \\
\text { Rate }\end{array}$ & $\begin{array}{l}\text { Number of } \\
\text { Marriages } \\
\text { (Numerator) }\end{array}$ & $\begin{array}{c}\text { Number of } \\
\text { Unmarried } \\
\text { Women Aged } \\
15+ \\
\text { (Denominator) }\end{array}$ & \\
\hline 1870 & $\theta$ & $\theta$ & & & Volume 1 of the Vital Statistics of the United States, 1950 \\
\hline 1880 & & 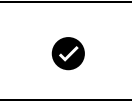 & $\bullet$ & IPUMS-USA & $\begin{array}{l}100 \text { years of marriage and divorce statistics United States } \\
1867-1967\end{array}$ \\
\hline 1890 & \multirow{5}{*}{$\ominus$} & \multirow{5}{*}{$\bullet$} & & & \multirow{5}{*}{$\begin{array}{l}100 \text { years of marriage and divorce statistics United States } \\
1867-1967\end{array}$} \\
\hline 1900 & & & & & \\
\hline 1910 & & & & & \\
\hline 1920 & & & & & \\
\hline 1930 & & & & & \\
\hline $1931-1939$ & 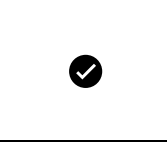 & 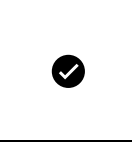 & & & $\begin{array}{l}\text { U.S. Bureau of the Census, Historical Statistics of the } \\
\text { United States, Colonial Times to 1957, Washington, D.C., } \\
\text { 1960, Library of Congress Card No. A 60-9150. }\end{array}$ \\
\hline $1940-1993$ & $\vartheta$ & $\theta$ & & & $\begin{array}{l}\text { Advanced Report of Final Marriage Statistics. Vital and } \\
\text { Health Statistics; Series 24, No } 6 .\end{array}$ \\
\hline 1994 & & $\odot$ & & IPUMS-CPS & $\begin{array}{l}\text { Vol. 43, No. 13. Annual Summary of Births, Marriages, } \\
\text { Divorces, and Deaths: United States, 1994. } 42 \text { pp. (PHS) } \\
\text { 96-1120. }\end{array}$ \\
\hline 1995 & & $\vartheta$ & & IPUMS-CPS & $\begin{array}{l}\text { Vol. 45, No. 12. Births, Marriages, Divorces, and Deaths } \\
\text { for } 1996.20 \text { pp. (PHS) 97-1120 }\end{array}$ \\
\hline $1996-1997$ & & $\theta$ & & IPUMS-CPS & $\begin{array}{l}\text { Vol. 46, No. 12. Births, Marriages, Divorces, and Deaths } \\
\text { for 1997. } 20 \text { pp. (PHS) } 98-1120\end{array}$ \\
\hline $1998-1999$ & & 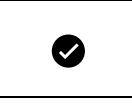 & & IPUMS-CPS & $\begin{array}{l}\text { Vol. 48, No. } 19 \text { Births, Marriages, Divorces, and Deaths: } \\
\text { Provisional Data for } 1999\end{array}$ \\
\hline $2000-2019$ & & $\theta$ & & IPUMS-USA & $\begin{array}{l}\text { CDC/NCHS, National Vital Statistics System, "National } \\
\text { marriage and divorce rate trends for 2000-2019", }\end{array}$ \\
\hline
\end{tabular}



Table 2. State-Level Data Sources

\begin{tabular}{|c|c|c|c|c|c|}
\hline \multirow[b]{2}{*}{ Year } & \multicolumn{4}{|c|}{ Measures } & \multirow[b]{2}{*}{ Source Title (for Adjusted Rate, Crude Rate, or Numerator) } \\
\hline & $\begin{array}{l}\text { Adjusted } \\
\text { Rate }\end{array}$ & $\begin{array}{c}\text { Crude } \\
\text { Rate }\end{array}$ & $\begin{array}{c}\text { Number } \\
\text { of } \\
\text { Marriages }\end{array}$ & $\begin{array}{c}\text { Number of } \\
\text { Unmarried Women } \\
\text { Aged 15+ } \\
\text { (Denominator) } \\
\end{array}$ & \\
\hline $\begin{array}{l}1890 \\
1900\end{array}$ & $\theta$ & & & & $\begin{array}{l}100 \text { years of marriage and divorce statistics United States 1867- } \\
1967\end{array}$ \\
\hline 1910 & \multicolumn{3}{|c|}{ Data Not Available } & & N.A. \\
\hline $\begin{array}{l}1930 \\
1940 \\
1950 \\
1960 \\
\end{array}$ & $\vartheta$ & & & & $\begin{array}{l}100 \text { years of marriage and divorce statistics United States 1867- } \\
1967\end{array}$ \\
\hline 1970 & 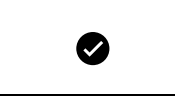 & & & & $\begin{array}{l}\text { Vital Statistics of the United States 1970, Volume III Marriage and } \\
\text { Divorce }\end{array}$ \\
\hline 1980 & & & $\theta$ & IPUMS-USA & $\begin{array}{l}\text { Advanced Report of Final Marriage Statistics. Vital and Health } \\
\text { Statistics; Series 24, No 6. July 14, } 1995\end{array}$ \\
\hline 1990 & & 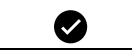 & & \multirow{4}{*}{ IPUMS-USA } & \multirow{4}{*}{$\begin{array}{l}\text { CDC/NCHS, National Vital Statistics System, "Marriage rates by } \\
\text { State: 1990, 1995, and 1999-2019." }\end{array}$} \\
\hline 2000 & & 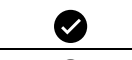 & & & \\
\hline 2010 & & 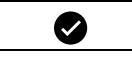 & & & \\
\hline 2019 & & $\theta$ & & & \\
\hline
\end{tabular}


Table 3. State-level Adjusted Marriage Rate Outliers, 1890-2019

\begin{tabular}{|c|c|c|c|c|c|c|c|c|c|c|c|}
\hline 1890 & 1900 & 1930 & 1940 & 1950 & 1960 & 1970 & 1980 & 1990 & 2000 & 2010 & 2019 \\
\hline Montana & Nevada & Arizona & Arizona & Alaska & Alaska & Alaska & Kentucky & Hawaii & Arkansas & Arkansas & Hawaii \\
\hline \multirow[t]{5}{*}{ Washington } & \multirow[t]{5}{*}{ Wyoming } & Nevada & \multirow[t]{5}{*}{ Nevada } & Arkansas & Idaho & Nevada & Nevada & Idaho & Hawaii & Hawaii & Idaho \\
\hline & & New & & Arizona & Nevada & South & \multirow{4}{*}{ Wyoming } & \multirow{4}{*}{ Nevada } & Nevada & Idaho & Nevada \\
\hline & & Mexico & & Mississippi & New & Carolina & & & Tennessee & Nevada & Utah \\
\hline & & & & Nevada & Mexico & & & & & Utah & \\
\hline & & & & New Mexico & $\begin{array}{l}\text { South } \\
\text { Carolina }\end{array}$ & & & & & & \\
\hline
\end{tabular}




\section{-----Adjusted Marriage Rate -Crude Marriage Rate}

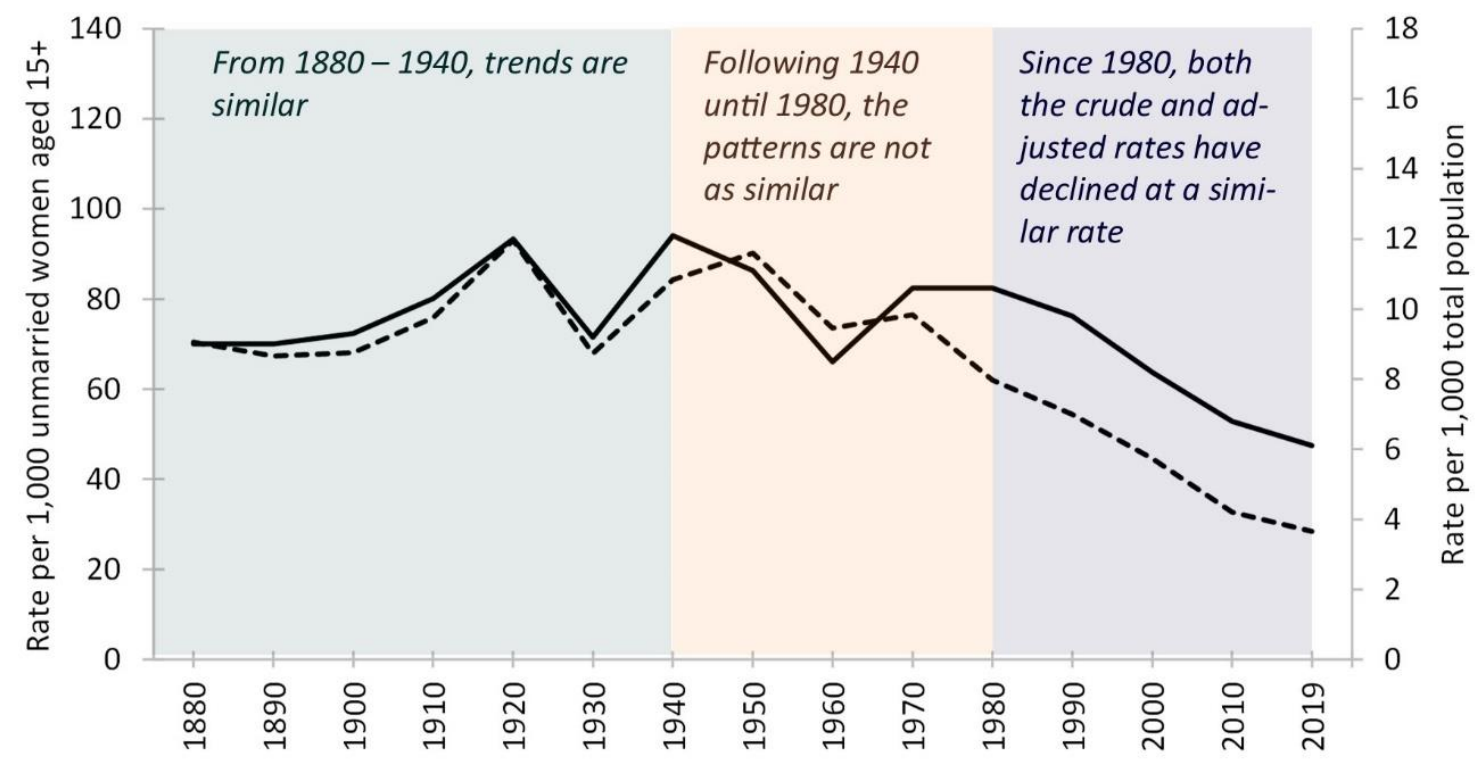

Figure 1. U.S. Decennial Marriage Rates, 1880-2019. Sources: See Table 1 


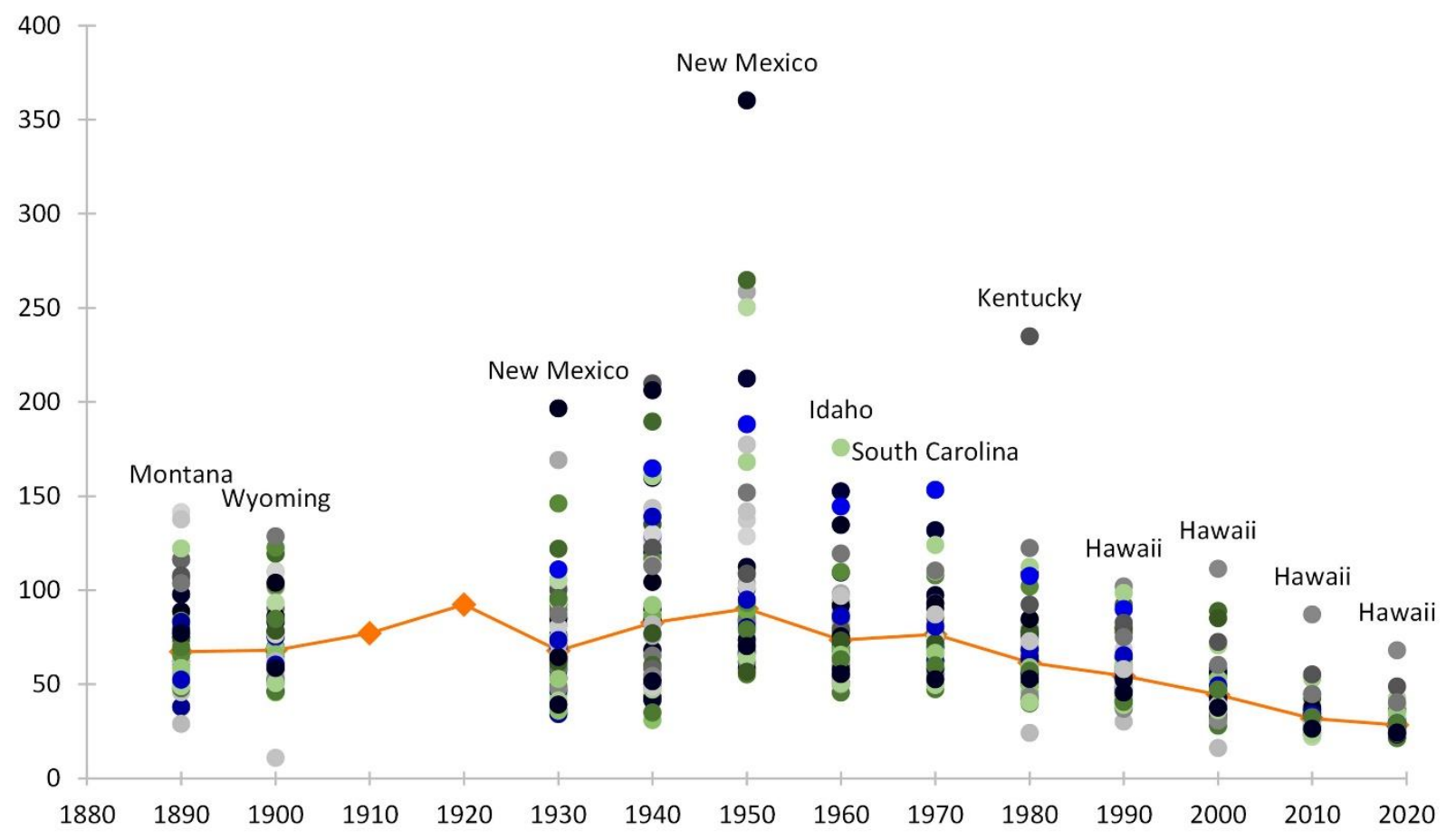

Figure 2a. State-level Adjusted Rates in the U.S., 1890-2019. Sources: See Table 2 
$\multimap$ - $\rightarrow$ Nevada

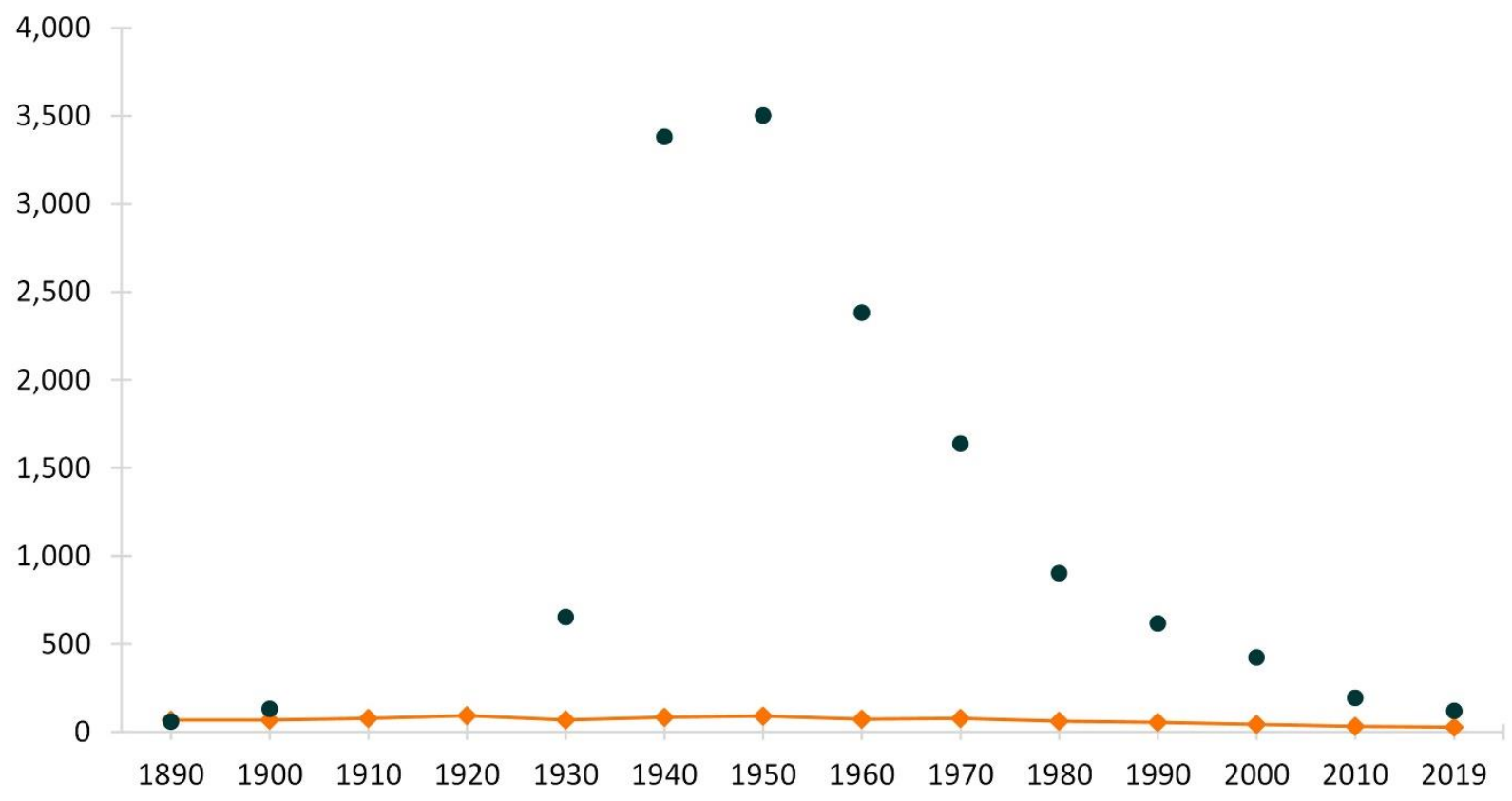

Figure 2b. Nevada and U.S. Adjusted Rates, 1890-2019. Sources: See Table 2

Note: Nevada was excluded from Figure 3a, because of its extremely high adjusted marriage rates. Including Nevada's rates would have caused so much distortion to the figure no other patterns would be evident. Nevada is referred to as a marriage "mill" -places where many out-of-state people are married. 


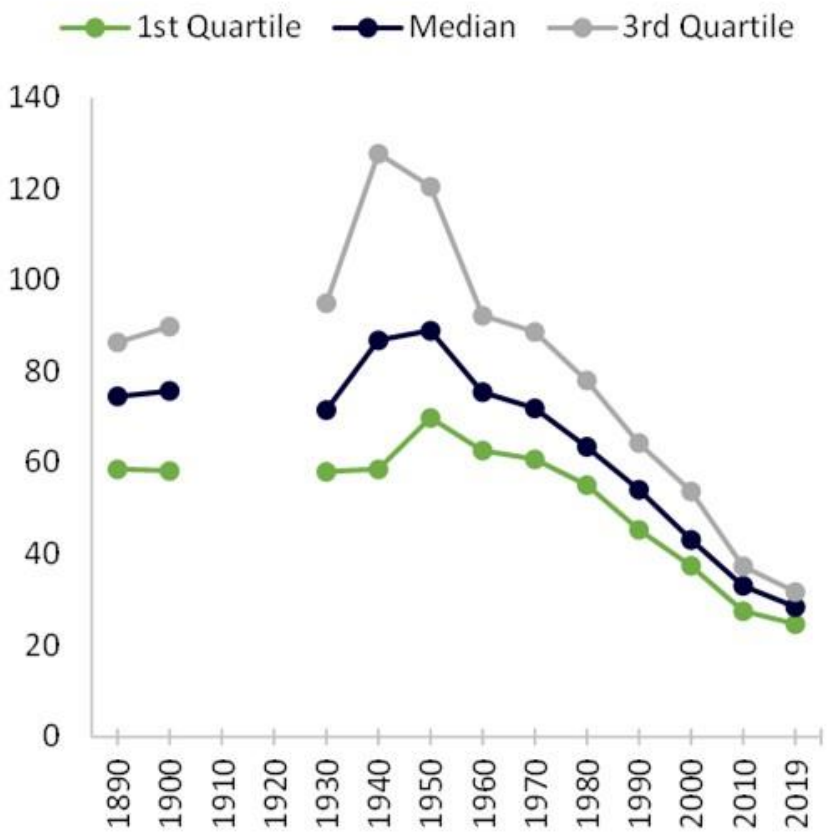

Figure 3a. Dispersion of State-level Adjusted Marriage Rates, 1900-2019. Sources: See Table 2 


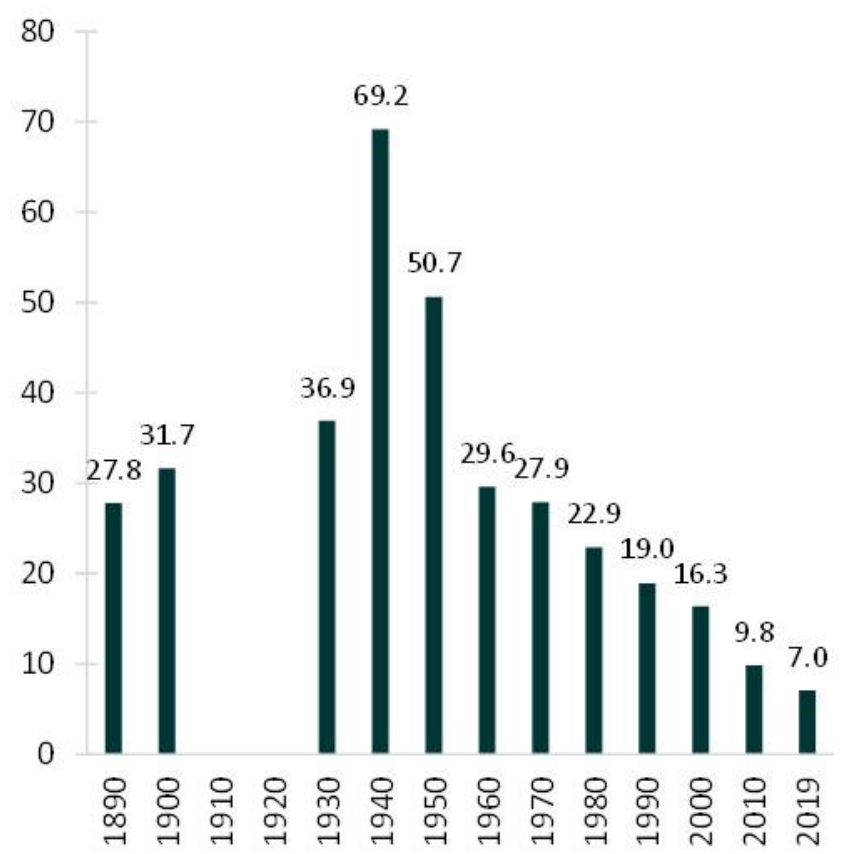

Figure 3b. Interquartile Range of State-level Adjusted Marriage Rates, 1900-2019 Sources: See Table 2 


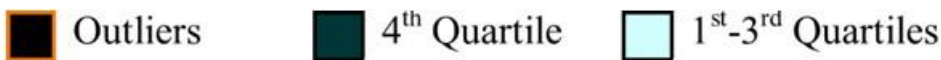

1890

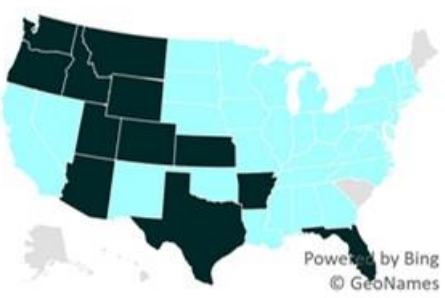

1940

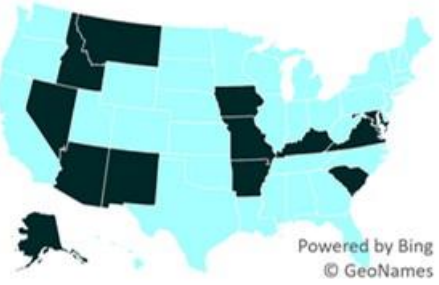

1970

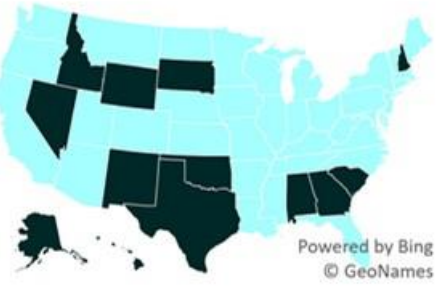

2000

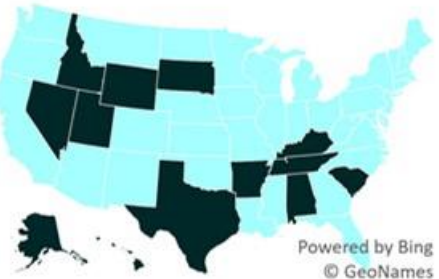

1900

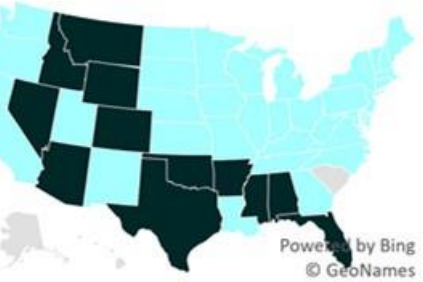

1950

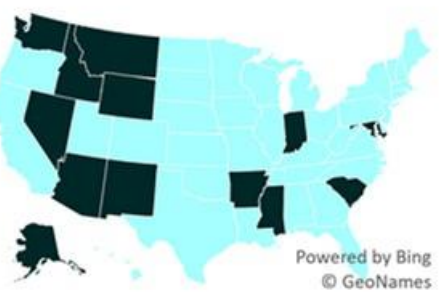

1980

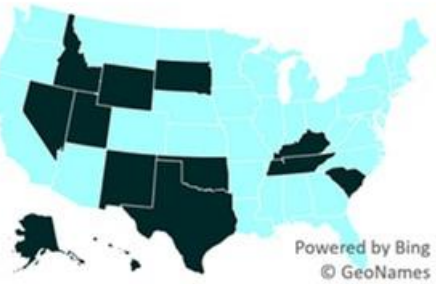

2010

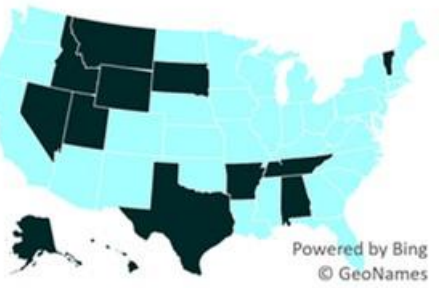

1930

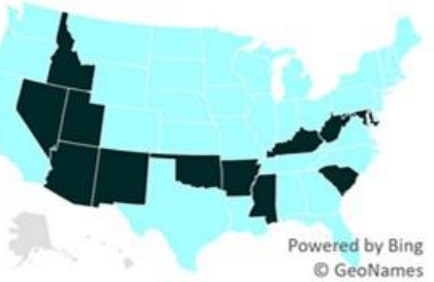

1960

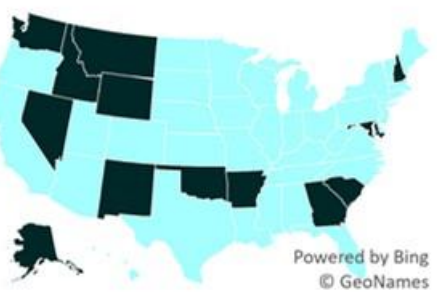

1990

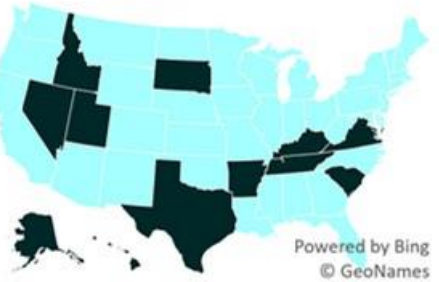

2019

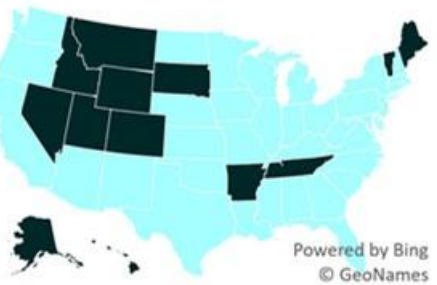

Figure 4 Maps Emphasizing States with High Adjusted Marriage Rates (4th Quartile) Relative to Other States, 1890-2019. Sources: See Table 2. 


\section{$\square 1^{\text {st }}$ Quartile $\square 2^{\text {nd }}-4^{\text {th }}$ Quartiles}

1890

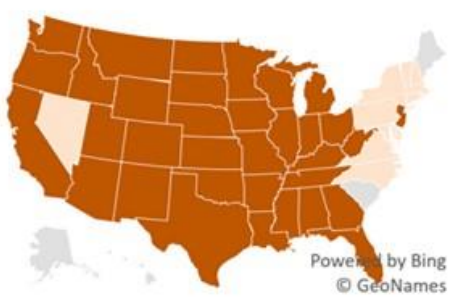

1940

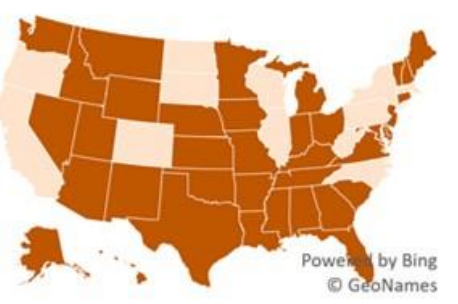

1970

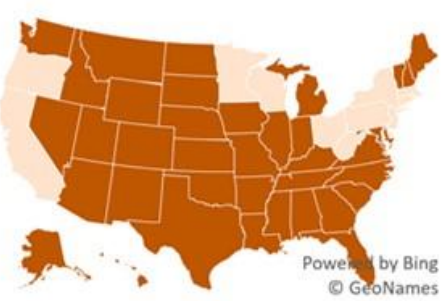

2000

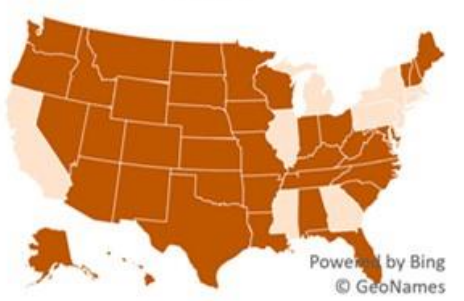

1900

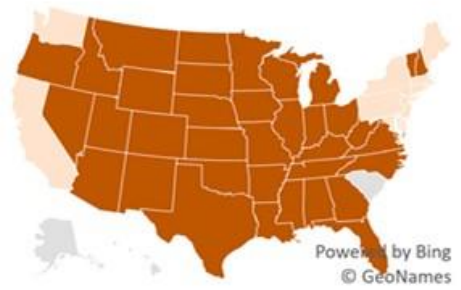

1950

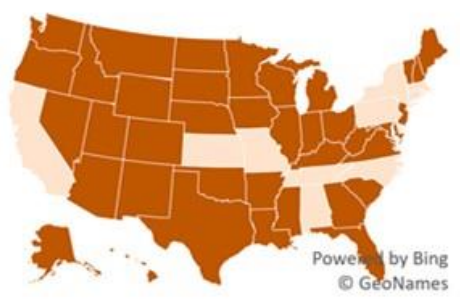

1980

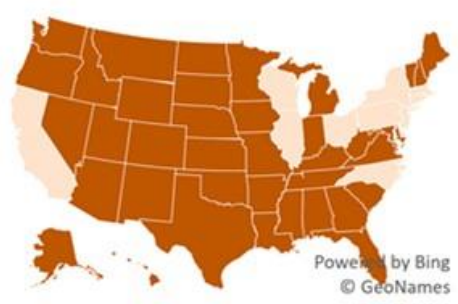

2010

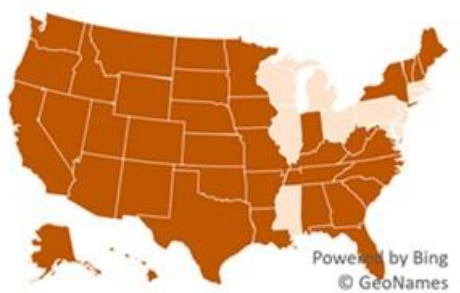

1930

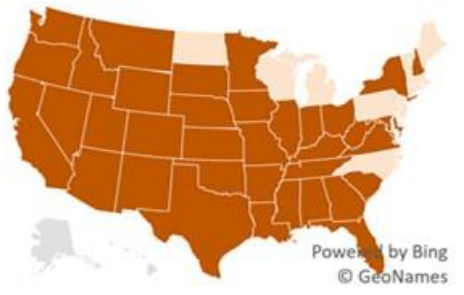

1960

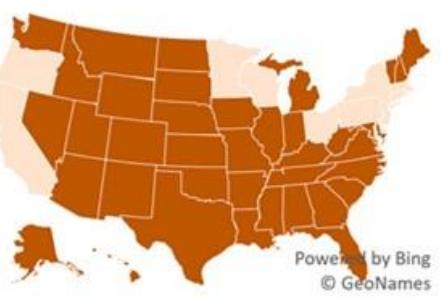

1990

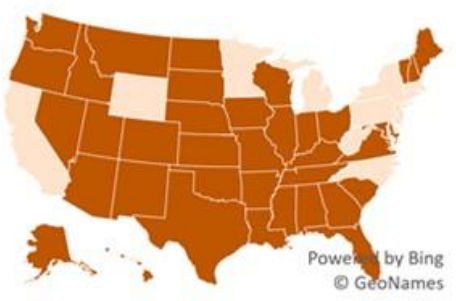

2019

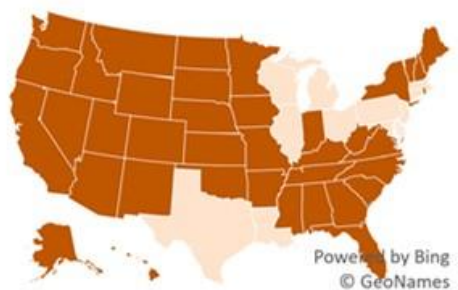

Figure 5. Maps Emphasizing States with Low Adjusted Marriage Rates (1st Quartile) Relative to Other States, 1900, 1930, 1960, and 2019. Sources: See Table 2. 